\title{
Food system sustainability standards: Room for everyone?
}

\author{
Keith Williams * \\ College of the North Atlantic, Carbonear Campus
}

Review of FAO/UNEP Workshop on Voluntary Standards for Sustainable Food Systems: Challenges and Opportunities, edited by Alexandre Maybeck \& Suzanne Redfern. (2014). Published by the Food and Agriculture Organization of the United Nations; 242 pages; available as free PDF. See more at the FAO website.

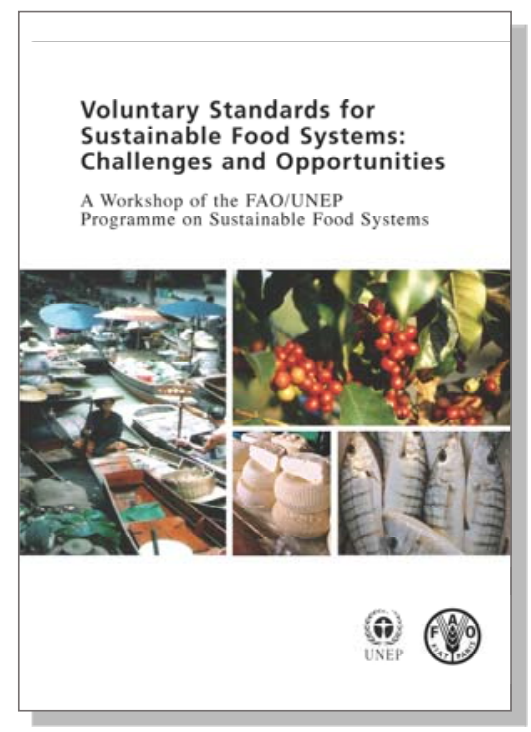

Submitted February 21, 2016 / Published online May 19, 2016

Citation: Williams, K. (2016). Food system sustainability standards: Room for everyone? [Book review]. Journal of Agriculture, Food Systems, and Community Development, 6(3), 163-166. http://dx.doi.org/10.5304/jafscd.2016.063.004

Copyright (C) 2016 by New Leaf Associates, Inc.

$F_{c}^{\text {in }}$ air-trade coffee is a familiar item in most stores now stock organic produce. These products are examples of voluntary sustainability standards (VSS) and were introduced into the Western marketplace in the 1980s. VSS "are voluntary schemes conveying information of relevance to sustainability about the process of production of

\footnotetext{
* Keith Williams, Campus Director, College of the North Atlantic, Carbonear Campus; 4 Pike's Lane; Carbonear, Newfoundland and Labrador, A1Y 1A7 Canada.
}

Keith Williams is the campus director at College of the North Atlantic's Carbonear Campus. He is an educator and applied researcher with an interest in promoting food sovereignty for Canada's Atlantic Provinces. Keith can be reached at keith.williams@,cna.nl.ca. specific products according to a reference standard or measurement" (Maybeck \& Gitz, 2014, p. 173, in Maybeck \& Redfern, 2014) and are typically implemented by businesses, assessed by third parties, and driven by consumer demand (Maybeck \& Redfern, 2014).

The past decade has witnessed a proliferation of VSS, driven by consumer demand for safe, high quality, and ethically and sustainably produced goods (Blackmore \& Keeley, 2012). VSS are a promising mechanism by which we might increase worker rights, enhance ecosystem services, and improve the quality of various goods. Even so, VSS schemes have come under criticism on a number of counts, such as excluding smallholder farmers and all farmers in low-income countries due to high certification and compliance costs. VSS (such 
as fair-trade) provide no provisions for greater benefits to farm employees above the accepted industry standards. Finally, the premiums charged for VSS products are consumed in support of the cooperatives and other associations necessary to manage the VSS designation (Henderson, 2008) rather than yielding higher returns to the smallholders producing goods for the fair-trade market.

In 2010, the Food and Agriculture Organization of the United Nations (FAO) and the United Nations Environment Program (UNEP) Sustainable Food Systems program formed an Agri-food Task Force composed of representatives from various governments, UN agencies, civil society organizations, and the private sector. The purpose of this task force was to develop a coordinated approach to sustainable consumption and production, share knowledge, build partnerships, and mobilize resources (Maybeck \& Redfern, 2010).

The workshop from which these proceedings were prepared was designed to address issues that would help the task force enhance VSS uptake and scaling, including making VSS work for small-scale producers, processors, consumers, and the private sector. The workshop also looked at exploring green trade opportunities and the role of the public sector in facilitating VSS.

I am currently living and working in the province of Newfoundland and Labrador, Canada. Newfoundland and Labrador produces only 10 percent of the food consumed domestically. Its isolation and lack of domestic food production make the province very vulnerable to transportation disruptions (Quinlan, 2012). In my own experience, grocery shelves are bare if the ferry does not make it across the Gulf of St. Lawrence. There is tremendous potential for increasing food production in Newfoundland. Voluntary standards might help to both increase the consumption of locally produced food and build a greater export market. My original desire in reviewing Voluntary Standards for Sustainable Food Systems was to learn more about how voluntary standards can help increase food sovereignty in Newfoundland and Labrador.

The workshop proceedings include a mix of academic research, field reports, case studies, and situational analyses. The work is written at a high level, appropriate for the intended audience-that is, members of the task force. However, despite the specific purpose of this document, there is still some value for a range of readers, including members of producer associations, food animators, policy makers, and researchers.

In one paper, Santacoloma (2014) identifies a concern regarding VSS: the exclusion of small-scale producers and food processors due to implementation costs imposed on them in order to achieve certification. This paper reports on a review of over 100 studies on the impact of VSS on smallholder market participation that found that VSS can facilitate smallholder capacity-building, thereby facilitating access to markets. This may be the case, for example, when there is a technical and business support package as a component of the certification process, or if a farm's size and assets are sufficient to support costs associated with certification. However, VSS can act as a barrier to smallholder market participation when smallholders lack the resources necessary for the initial investment in the certification process or if rural agricultural infrastructure is underdeveloped (Loconto \& Dankers, 2013, in Santacoloma, 2014).

In another paper, Loconto and Santacoloma (2014) synthesize key lessons after studying VSS schemes in various countries. They found that projects had higher chances of success based on the following factors:

- if a market already exists for a given certified product;

- if cost-benefit analysis is conducted to determine project feasibility;

- if support exists beyond certification and governance systems to ensure continued capacity building and product guarantees; and

- if an evaluative approach is built into project planning to support evidence-based decision making.

Both this paper and the one prepared by Santacoloma (2014) provide suggestions that could be of value to agriculture industry associations or other community food animators interested in implementing a VSS scheme. 
In another paper published in the proceedings, Antonelli, Al-Bitar, and Pugliese (2014) describe experiences with quality labeling in the Mediterranean region and highlight some case studies in which VSS have helped to build capacity for smallholder farmers and processors. For example, they report on a federation of women olive-oil producers in the mountainous Rif region of northern Morocco. The group organized to produce higher quality oil and other diverse agricultural and valueadded products. A VSS quality designation helped them maintain traditional knowledge, diversify their output, enhance their standard of living, secure support from their regional governments, and upgrade processing equipment to an international standard. The authors of this paper wisely caution that national and regional capacity for quality monitoring must be factored into VSS project design.

Pastore (2014) outlines the role of the FAO in engaging with the private sector, which the FAO defines broadly as including farmer organizations, cooperatives, enterprises, industry and trade associations, research and academic institutions, and more. Areas of engagement are discussed in this article. However, despite the FAO being subject to the 2007 United Nations Declaration on Rights of Indigenous Peoples, there is no discussion of provisions to support market access for Indigenous peoples, who are considered a globally marginalized demographic. This failing does not rest at Pastore's feet exclusively; only three articles in the proceedings mention traditional knowledge (TK) or Indigenous rights.

One of the more interesting articles in the collection presents a study describing how a protected designation of origin (PDO) designation was used to reassure consumers regarding the quality of earthquake-damaged Parmigiano-Reggiano cheese ("Parmigiano-Reggiano damaged by earthquake," or PR-T) in May 2012 (Finardi \& Menozzi, 2014). In the article, the authors propose that PDOs can be used as tools for regional resilience in the face of disaster. They described marketing and sales of PR-T, championed by Coldiretti (the primary Italian farmers' union), as "bottom up, selforganizing....and characterized by deep emotional participation by consumers" (Finardi \& Menozzi,
2014, p. 152). The authors delivered a questionnaire to 200 consumers to elicit feedback on consumer demographics and behavior (past behavior, behavior post-earthquake, and motivations). They discovered that social networks played a prominent role in consumers' decisions to purchase PR-T and suggest that a 'sense of belonging' influenced consumer behavior as well. They ground these observations in 'embeddedness' theory (Polanyi, Arensberg, \& Pearson, 1957, in Finardi \& Menozzi, 2014), which suggests that social relationships underpin and shape economic relationships. The implications for disaster-affected regions with large diaspora populations are significant. For example, a coordinated effort to support VSS for some artisanal Syrian food producers could help to create pockets of stability in Syria and other countries in the region affected by the Islamic State. The results presented in this article are also tantalizing when considering Atlantic Canada's food sovereignty. As a Nova Scotian and a resident of Atlantic Canada, I recognize that Atlantic Canadians have a strong sense of place. There are generations of economic migrants from Canada's Atlantic Provinces who have relocated across Canada and beyond for work (Nolan, 2007). This vast diaspora with a strong attachment to their home provinces could play a role in increasing the viability of small-scale food production here, particularly using VSS as a means to identify Atlantic food products.

Contributing authors emphasize the important issue of smallholder participation in VSS. Much of the extant data presented or drawn on in these proceedings suggest that collective action by farmers and value-added producers is critical for smallholder uptake and scheme success. Despite UN and UN-FAO commitments to equity for Indigenous peoples (FAO, 2010; UN General Assembly, 2007), there is little mention and no discussion regarding supporting VSS adoption and market access for Indigenous farmers and value-added food producers. Gender mainstreaming, a strategic objective for the FAO (FAO, 2009), also receives short shrift. Women's participation in VSS is discussed, but almost as a footnote, without analysis regarding inclusionary needs or discussion of best practices, thereby leaving the steps to effective gender mainstreaming a mystery. Overall, the 
proceedings effectively highlight current thinking around VSS and make recommendations for successful implementation of VSS in a variety of contexts. The contributors take particular care in discussing smallholder inclusion. Despite the shortcomings of this particular volume, I believe voluntary standards have potential for enhancing smallscale food production in Newfoundland and Labrador, especially if provisions are made to include Indigenous food producers and women.

\section{References}

Antonelli, A., Al-Bitar, L., \& Pugliese, P. (2014). Stories behind quality labels around the Mediterranean countries. In Maybeck, A., \& Redfern, S. (Eds.), FAO/UNEP Workshop on Voluntary Standards for Sustainable Food Systems: Challenges and Opportunities (pp. 65-75). Rome: Food and Agriculture Organization of the United Nations [FAO]. Retrieved from http://www.fao.org/familyfarming/detail/en/c/273709/

Blackmore, E., \& Keeley, J. with Pyburn, R., Mangus, E., Chen, L., \& Yuhui, Q. (2012). Pro-poor certification: Assessing the benefits of sustainability certification for small-scale farmers in Asia (Natural Resource Issues No. 25). London: International Institute for Environment and Development. Retrieved from http://www.european-fair-tradeassociation.org/efta/Doc/Propoorcert-IIED.pdf

Finardi, C., \& Menozzi, D. (2014). PDOs' role in reassuring consumers: The "Parmigiano Reggiano Terremotato" case. In Maybeck, A., \& Redfern, S. (Eds.), FAO/UNEP Workshop on Voluntary Standards for Sustainable Food Systems: Challenges and Opportunities (pp. 151-170). Rome: FAO. Retrieved from http://www.fao.org/family-farming/detail/ en/c/273709/

Food and Agriculture Organization of the United Nations [FAO]. (2009, October). Strategic framework 2010-2019. Notes from conference in Rome. Retrieved from http://www.fao.org/docrep/ meeting/029/k5864e01.pdf

FAO. (2010). FAO Policy on Indigenous and Tribal peoples.

Rome: FAO Office of Knowledge Exchange, Research, and Extension. Retrieved from http://www.fao.org/fileadmin/user upload/ newsroom/docs/FAO policy.pdf
Henderson, D. R. (2008). Fair trade is counterproductive - and unfair. Economic Affairs, 28(3), 62-64. http://dx.doi.org/10.1111/j.1468-0270.2008. $00847 . x$

Loconto, A., \& Santacoloma, P. (2014). Lessons learned from field projects on voluntary standards: Synthesis of results. In Maybeck, A., \& Redfern, S. (Eds.), FAO/UNEP Workshop on Voluntary Standards for Sustainable Food Systems: Challenges and Opportunities (pp. 45-63). Rome: FAO. Retrieved from http://www.fao.org/family-farming/detail/ $\underline{e n / c / 273709 /}$

Maybeck, A., \& Redfern, S. (Eds.). (2014). FAO/UNEP Workshop on Voluntary Standards for Sustainable Food Systems: Challenges and Opportunities. Rome: FAO. Retrieved from http://www.fao.org/familyfarming/detail/en/c/273709/

Nolan, S. (2007). Leaving Newfoundland: A bistory of outmigration. St. John's, Newfoundland: Flanker Press.

Pastore, A. (2014). FAO's strategic vision to engage with the private sector. In Maybeck, A., \& Redfern, S. (Eds.), FAO/UNEP Workshop on Voluntary Standards for Sustainable Food Systems: Challenges and Opportunities (pp. 105-119). Rome: FAO. Retrieved from http://www.fao.org/family-farming/detail/ en/c/273709/

Polanyi, K., Arensberg, C. M., \& Pearson, H. W. (1957). Trade and market in the early empires: Economies in history and theory. New York: Free Press.

Quinlan, A.J. (2012). Building agricultural capacity in Newfoundland and Labrador. St. John's, Newfoundland: Harris Centre of Memorial University. Retrieved from https://www.mun.ca/harriscentre/reports/ arf/2011/11-SPHCSRF-Final-Quinlan.pdf

Santacoloma, P. (2014). Nexus between public and private food standards: Main issues and perspectives. In Maybeck, A., \& Redfern, S. (Eds.), FAO/UNEP Workshop on Voluntary Standards for Sustainable Food Systems: Challenges and Opportunities (pp. 11-23). Rome: FAO. Retrieved from http://www.fao.org/family-farming/detail/en/ c/273709/

United Nations General Assembly. (2008). United Nations declaration on the rights of Indigenous peoples: Resolution adopted by the General Assembly. Retrieved from http://www.un.org/esa/socdev/unpfii /documents/DRIPS en.pdf 